\title{
In Response to Coraci et al
}

We read with great interest the letter by Coraci et al, which mentioned particular utilization of ultrasound in the assessment of entrapment neuropathies.

They emphasized the benefits of the ultrasound providing morphologic information like anatomical variations throughout their educationally valuable case report (1). They have clearly mentioned that evaluation of peripheral nerve lesions both with electromyography and ultrasonography obviously increase the rate of correct diagnosis.

Beside the anatomical scaning utility, we also want to mention the important role of ultrasound supporting the electrophysiological techniques. Ultrasound is a perfect tool to guide needle localization which is difficult to localize especially at the potentially risky muscles such as intercostal muscles (2). It is found that in electromyographic studies non-guided needle placement was significantly less accurate than ultrasoundguided needle placement (3). Ultrasound is also useful for nerve conduction studies especially for small and challenging nerves such as dorsal ulnar cutaneous or superficial radial nerve and even for sural nerve in some cases (3).

So, it is believed that ultrasound could also increase the diagnostic utility of the electromyographic examination. Throughout all these diagnostic advantages it is better to consider these two diagnostic modalities not competing, but instead cooperative tools (4). As it is sugggested (2), we also recommend to have the ultrasound and electromyography instruments in the same examination room for the numerous advantages of using them together.

Elif Yalcin, MD

Ankara Fizik Tedavi

Rehabilitasyon Egitim ve

Arastırma Hastanesi Turkocagı

Sokak Sihhiye-Ankara- Turkey

E-mail: elifyalcin78@gmail.com

Mufit Akyuz, MD

Ankara Fizik Tedavi

Rehabilitasyon Egitim ve

Arastırma Hastanesi Turkocagı

Sokak Sihhiye-Ankara- Turkey

E-mail: mufitakyuz@yhaoo.com

Ece Unlu, MD

Ankara Diskapi Yildirim Beyazit

Training and Research Hospital

of the Ministry of Health,

Ankara, Turkey

E-mail: dreceunlu@yahoo.com

\section{References:}

1. Coraci D, Luchetti R, Paolasso I, Santilli $V$, Padua L. Intermittent ulnar nerve compression due to accessory abductor digiti minimi muscle: Crucial diagnostic 3 role of nerve ultrasound. Muscle \& Nerve 2015; Mar 25, doi:10.1002/mus.2466o.

2. Strakowski JA, Ultrasound Evaluation of
Focal Neuropathies: Correlation with Electrodiagnosis, Demos Medikal, New York, 2014.

3. Boon AJ, Oney-Marlow TM, Murthy NS, Harper CM, McNamara TR, Smith J. Accuracy of electromyography needle placement in cadavers: non-guided vs. ultrasound guided. Muscle Nerve. 2011; 44:45-49. doi: 10.1002/mus.22008.

4. Vanderstraeten G. No need to compete, better to cooperate. J Rehabil Med 2013; 45:606. doi: 10.2340/165019771163. 